\title{
1. Introduction: the political constitution of the corporation
}

\section{VIGNETTE: THE SOCIAL SIGNIFICANCE OF CONFLICT}

At times, the social sciences are neatly divided into a conflict-oriented camp, with Karl Marx as the radical alternative and Max Weber as the more moderate choice, on the one hand, and a consensus-oriented camp with Émile Durkheim as the patron saint, on the other. Such a dual separation of the social sciences is naturally a primitive classification system that helps to sort out generic perspectives for the benefit of scholarly debates, and to lower entry barriers for neophytes and aspiring scholars. However, such classificatory disciplining of heterogeneous contributions into neatly compartmentalized categories is only the starting point when learning to know the social science literature in greater detail.

George Simmel is arguably the classic social theorist who has done the most to transgress the boundary between conflict and consensus-oriented social theory. In Simmel's view, conflict and collaboration do always co-exist in social relationships and in society more widely. "Society," Simmel (1955: 15) writes, "needs some quantitative ratio of harmony and disharmony, of association and competition, of favorable and unfavorable tendencies." A society devoid of conflict loses its dynamic and becomes uninventive and reveals an impaired capacity to change; a society characterized by ceaseless conflict exhausts its members and cannot canalize its capacity for renewal in meaningful ways. In this view, Simmel (1955: 14) says, conflict is not "pure negativity," but "conflict contains something positive." For instance, Simmel talks about competition as a typical form of conflict, between two or more market actors, who compete over market shares and the economic and social benefits (e.g., status) derived therefrom. From a social theory perspective, such competition contributes to net economic welfare, as it incentivizes the participants to make use of productive resources in a meaningful way: "[F]rom the standpoint of society, [competition] offers subjective motives as the means of producing objective social value; and from the standpoint of the competing parties, it uses the production of objective value as means for attaining sub- 
jective satisfaction," Simmel (1955: 60) argues. Conflict qua competition is in short a meaningful social mechanism that contributes to socio-economic welfare and creates meaning in the eyes of the individual who participates in the market activities.

Coser (1956: 25) argues that the social science literature he reviews either avoids the issue of conflict altogether, or treats it as a "pathological condition which upsets the normal state of community equilibrium." Speaking more explicitly about the social group (the community, the work team, the family, etc.), Coser (1956: 31) argues that "[n]o group can be entirely harmonious, for it would then be devoid of process and structure." Social theorists thus tend to underestimate the value of conflict and controversy as a mechanism that channels ideas and helps to articulate preferences - the true demon of the social scientist's analytical framework, constantly changing and in many cases being vaguely fathomed even by the social actor him- or herself (March, 1978: 596) - and thus dismiss conflict as a failure or a dysfunctional condition. In contrast to this view, Coser (1956: 31), following Simmel (1955), argues that "groups require disharmony as well as harmony, dissociation as well as association; and conflicts within them are by no means altogether disruptive factors." Expressed differently, social harmony and consensus are transient stages in social development, preceded and succeeded by episodes of conflict and disputes, and consensus equilibria are reached only through the articulation of conflictual views and preferences and their reconciliation on the basis of deliberation.

Coser (1956: 49) makes a distinction between realistic and non-realistic conflicts, wherein the former address inconsistencies in how groups are maintained and led, whereas the latter are driven by "the need for tension release" of at least one of two or more antagonists. Coser thus recognizes that social actors can generate conflicts deliberately to advance their own interests or on the basis of individual preferences. That is, non-realistic conflicts may impose additional costs that add little value to the group's functioning or performance. This theoretical complication does not reduce the value of Simmel's insight, that social communities are preferably defined by their conflicts or their capacity to make agreements, but that these two ends of the continuum need to be balanced in meaningful ways.

The term politics used in the title of this volume is indicative of this Simmelian enfolding of conflict and consensus, controversy and collaboration, disputes and agreements. Politics is indeed a fuzzy term, but it is a concept and a practice that honors Euripides' claim (cited in Plutarch, 1992: 230) that, "Good and bad are inseparable, but blending is possible, to make things fine." There are many ways to make things fine, and politics is one such instrument in the hand of social communities. Still, to recognize the interdependencies of conflict and consensus is merely a starting point for a broader engagement with 
social relations, and this volume will locate such an ongoing debate within the realm of the business organization, the corporate device, per se, being a creation within the legislative sovereign state in the nineteenth century and thereafter assuming a central role in the contemporary economy. The view taken on the business organization is overtly Simmelian inasmuch as it does recognize the needs to let opposing views be articulated and discussed to fully exploit the possibilities of the chartered business, yet its operations demand at least a minimal degree of consensus. In this view, the political constitution of the corporation should be simultaneously honored and subject to criticism, or else this legal invention may cease to serve a meaningful role in the contemporary economy.

\section{INTRODUCTION: ORGANIZATIONAL POLITICS AND OTHER POLITICAL MODALITIES}

"To err is human, To blame someone is politics," is a bon mot attributed to Hubert Humphrey (1911-1978), U.S. Vice President during the 1965-1969 period (cited in Hood, 2011: 181), and Richard M. Nixon's (unsuccessful) opponent in the 1968 presidential election. While this statement is poorly qualified as a formal and comprehensive definition of politics as a form of social and cultural practice, wherein competition over attention, authority, influence, and social recognition is unavoidable, it captures the soft underbelly of politics, its exposure to human weaknesses. Furthermore, the concept of politics (or the clunky academic construct "the political," which assumes some kind of realist epistemology wherein political matters can be captured "as they are," as some kind of tangible entity to be examined and dissected) is frequently introduced as some kind of residual social mechanism whenever all other means to handle social issues and affairs have been exhausted. In this view, politics and all its practices and routines including deliberation, negotiation, bargaining, and horse-trading, enter the scene only when there are no other possibilities for reaching an agreement. Furthermore, like all efficient social practices, there is an element of invisibility in politics inasmuch as the skilled politician (i.e., a member of a professional category) or political actors (any professional agent who seeks to make use of political practices in the socio-economic realm) may effectively veil the interests and power-imbalances of political decision making. "Politics is the art of making things visible and making them count while making other things disappear," Kornberger (2012: 98) proposes. At the same time, politics is naturally surrounded by skepticism and critical assessments, and to be able to operate in politicized domains demands both detailed expertise of the rules of the game and sang-froid. Ultimately, politics and efficient political deliberation are the outcome from convoluted social processes wherein terms such as "rationality" are defined en route and on the basis of the 
actual decisions being made and announced, to some extent being qualified as being more or less rational. As Lakoff and Klinenberg (2010: 523) remark on the basis of their study of budgeting processes at the U.S. Homeland Security Department, responsible for the protection of U.S. citizens in an era of growing terrorist activities, '[t] $]$ he distinction between 'rationality' and 'politics' does not exists a priori, but rather is defined in the concrete political and technical struggle over the creation of a decision tool." Political processes are at their very heart activities wherein grand terms such as "rationality" are filled with meaning and associated with specific practices, i.e., they performatively define what rationality is. Not only is politics being developed in its own making, it is also irreducibly a social process and practice wherein heterogeneous interests co-exist and wherein interests and preferences change over time, occasionally quite dramatically over just days or even hours as new information is introduced in, e.g., policy making or budgeting processes. Politics is thus the domain of decision making wherein the question of " $[\mathrm{h}]$ ow to reach a fair and efficient compromise given the many conflicting preferences expressed in the political community" (Miller, 1992: 55) is of central importance.

This is not a treatise in the discipline of political science, and nor is it intended to be a management studies scholar's personal account of how the term "politics" can be interpreted and understood. It is instead a volume that addresses how the corporation as a legal device is subject to what is here referred to as a political economy wherein various forms of political conditions and political activities need to be included in the analysis of the construct of the corporation and its day-to-day operations, not the least its governance decision determining the medium- to long-term use of firm-specific economic resources. Schmidt et al. (2012: 76) make a distinction between "Big Politics," defined as a set of attempts that seek to formally codify and institutionalize political decisions, values, and actions, and "micropolitics," defined as "a set of interrelated attempts to open up politics to new actors, to find a space for various others to speak and transform a collective." The difference between "big" and "not so big" politics thus indicates the degree of institutionalization, how well prepared and trained the political agent is, and what kind of resources he or she deploys in his or her pursuit to advance specific ideas. The perspective taken in this book is perhaps best defined as a form of meso-level politics, wherein corporate entities and their defined agents (say, lobbyists, or politicians being supported through direct campaign contributions) operate to accomplish goals that are beneficial for their primary objective, to compete successfully in the marketplace, and to report an adequate return-on-investment (or some other performance measure of choice). In this meso-level perspective, the political system is approached as a means to support economic goals, and the political work is therefore only secondary to the primary economic goals and strategic objectives. However, in a highly regulated market system, wherein the state 
and transnational agencies closely monitor industry activities and continuously implement new policies, new legislation, and novel regulatory control practices, there are strong incentives for corporations to actively intervene into the process to strengthen their position vis-à-vis competitors, or to otherwise ensure benefits for the corporation or the industry more largely. Seen in this view, the political milieu or the political climate can be shaped and informed on the basis of various political activities initiated and monitored by the corporation. In addition, the corporation is a legal invention and a legal device established within the sovereign state's legislative process. This condition further emphasizes the political economy of the corporation, as the corporation was originally developed to promote enterprise and venturing in the formative years of competitive capitalism, and within the political constitution of the sovereign state per se. Expressed differently, the legal device of the incorporated business was from the outset a creation of the state, which also justifies a political economy view of the corporation. That is, despite being associated with market-based transactions and production activities, the corporation is itself foremost an outcome from political deliberation and legislative processes, and acts as a political entity when it hires lobbyists or finance think tank scholarship to better support medium- to long-term industry interests. The corporation is thus a primary political actor in the era of a highly differentiated, globalized, and finance-led economic regime.

The concept of politics is perhaps an overused word outside the political science discipline. Social theorists tend to use the term politics not so much to denote a defined political system but as a general term to indicate that there are controversies and diverging interests associated with some defined issue. In this view, there are "politics" everywhere, to the point where the term almost ceases to be a meaningful signifier of some underlying referent. For instance, Latour (2004: 221) proposes that "[a]ny epistemology is a political epistemology," inasmuch as it is never a question of "elaborating a theory of knowledge only, but always also a principle for mapping a divide between science and politics." At the same time, this ubiquitous presence of politics in all scientific procedures, from the laboratory research and outward, into the wider society and within, say, policy making processes wherein scientists are still trusted agents who present purportedly "objective knowledge," is not yet accepted across the board. "Science is not politics pursued by other means," Lenoir (1997: 14) argues: "[S]cientific work itself, even in the most 'disinterested' fields of inquiry such as the abstract field of mathematics, is unthinkable without the objective conditions giving rise to and supporting it." In social theory, therefore, the term politics is somewhat bruised from its overuse or from inadequate or misleading applications of the term, which makes it a complicated concept to apply when constructing a theory of the corporation. Furthermore, there is a tendency in the social sciences to bestow 
agency upon various nonhuman (in the actor-network theory framework) or technical entities, including animals (Haraway. 2008), artifacts (Rennstam, 2012: Preda, 2006), and texts (Cooren, 2004). Whenever the term politics is invoked, the concept of agency follows suit (Berg, 1998; Winner, 1980), which denotes social processes wherein such agencies are operationalized, enacted, and maintained, and gradually inform organizational practices (see e.g., Compagni, Mele, and Ravasi, 2015; Barrett et al. 2012; Barley, 1986). This view certainly has served to broaden the scope of the role of artifacts and technologies in organizations, but it has also served to make the term politics more fuzzy and increasingly associated with general epistemological disputes over the nature of things and their relations in a social context.

Based on this (critical) review of the social science literature, the concept of politics needs a rehabilitation to serve the ends of this volume, namely to portray the corporation as an irreducibly political entity, both by its legal and regulatory construction, and on the basis of its various activities aimed at shaping the milieu wherein the corporation operates. In order to pursue these goals, a somewhat more unfashionable and somewhat threadbare literature will be used, including the work of Jeffrey Pfeffer (1981: 7), distinguishing between power and politics in organizations insofar as "power is the property of the system in rest; politics is the study of power in action." Based on this systemic definition of power, also being non-Marxist, non-Weberian, etc., i.e., a "non-critical" view of power (characteristic, some commentators would say, of the business school credo), Pfeffer (1981: 7) introduces the term "organizational politics." This class of political action includes "activities taken within organizations to acquire, develop, and use power and other resources to obtain one's preferred outcomes in a situation in which there is uncertainty or discussions about choices" (Pfeffer, 1981: 7). As "uncertainty or discussions about choices" is a situation that is most likely to exist in a variety of situations, and under different conditions (see e.g., March, 1978), this is neither an entirely satisficing definition of organizational politics, nor a statement indicative of the polymorphous presence of politics in corporations. However, as Richard and Smith (2017: 95) remark, "following a long hiatus, the relationship between business and politics has reemerged in recent years as a compelling concern for historians of the United States," and the current incomplete and under-substantiated concept of organizational politics can be justified on such grounds. In this context, organizational politics is intended to serve as a value-neutral term that denotes how a variety of organizational practices are inherently political in nature, and that organizations frequently participate in political activities and processes to benefit their own interests. Seen in this view, organizational politics is a term faute de mieux that still is serviceable when operationalizing the fluid and fuzzy term of politics. In this view, organizing is politics pursued by other means. 


\section{DEFINING KEY TERMS}

In order to construct an analytical framework wherein the concept of the corporation can be examined in detail, a set of key analytical terms needs to be defined. Beckert (2013: 327) defines capitalism as an integrated economic system accordingly: "Capitalism can be defined as an endemically dynamic economic system in which the production of goods and services is motivated by expected profits, materializing in market exchanges." This definition of capitalism is consistent with Max Weber's (1999: 48) characterization of capitalism as an integrated economic system, which includes numerous co-produced mechanisms and conditions: "We have recognized as characteristics and pre-requisites of capitalist enterprise the following: appropriation of the physical means of production by the entrepreneur, freedom of the market, rational technology, rational law, free labor, and finally the commercialization of economic life." Joseph Schumpeter (1928) regarded the capitalist economic system as being essentially unstable, unpredictable, and protean, as it includes many destabilizing mechanisms, including market speculation, information asymmetry, and information costs. At the same time, Schumpeter (1928: $385)$ argued, over time the economic system of capitalism gradually becomes "automatized" and "impersonalized," no longer dependent on leadership and individual initiative. This paradoxical nature of capitalism, its ability to operate as a form of "post-heroic" social and economic system (Schumpeter always thought that capitalism was mutually propelled by, and feeding into social norms and beliefs), yet creating its own critique and discontent as economic wealth is generated and unequally distributed (as have been demonstrated to be the case by historical records; Scheidel, 2017), is both the curse and the blessing of the capitalist economic system. Ultimately, Schumpeter dourly predicted, partially informed by his reading of the works of Karl Marx, capitalism is at risk of generating its own demise as the rising standards of living, brought by the efficiency of economic activities and markets, tend to result not so much in a stated commitment to the economic model but its opposite, a persistent critique of its functioning:

Capitalism, whilst economically stable, and even gaining in stability, creates, by rationalising the human mind, a mentality and a style of life incompatible with its own fundamental conditions, motives and social institutions, and will be changed, although not by economic necessity and probably even at some sacrifice of economic welfare, into an order of things which it will be merely matter of taste and terminology to call Socialism or not. (Schumpeter, 1928: 385-386)

In this Schumpeterian model of capitalism, which underlines its dynamic nature and its social embedding, the economic system as such needs to be 
protected by an institutional framework. In other words, Schumpeter anticipated an institutional view of the capitalist economic system wherein certain institutions both monitor and regulate the capitalist mode of production and the market system, and thereby justify their existence and operations vis-à-vis their critics.

Fligstein (1996) advocates "a political-cultural approach to market institutions" along these lines, and stresses an economic sociology view of certain economic entities. First of all, Fligstein (1996: 658) defines markets in dynamic and practice-based terms as "situations in which some good or service is sold to customers for a price that is paid in money (a generalized medium of exchange)." Second, institutions are defined as "shared rules, which can be laws or collective understandings, held in place by custom, explicit agreement, or tacit agreement." Third and finally, the term governance structure, central to the operation of markets and economic entities that operate in markets, refers to "the general rules in a society that define relations of competition, cooperation, and market-specific definitions of how firms should be organized." Within the overarching concept of capitalism, markets, and institutions, governance structures (or governance practices) serve to generate economic welfare. The shift from treating capitalism as a stable and largely predictable economic system, vital in the pursuit of understanding its constitutive mechanisms and entities, yet limited in scope, to a dynamic view of capitalism is key to the scholarship of the political economy of the corporation. In order to point to the analytical value of these theoretical terms, empirical cases need to be introduced.

As recognized by Schumpeter and his various followers, which include economic sociologists and management scholars, the capitalist economic system is defined on the basis of its capacity to continuously integrate new elements and respond to social needs, and to modify and adjust as novel conditions and opportunities emerge. The incorporated business venture- the corporation - constituted and protected by corporate law, is a key entity in the received capitalist economic model at hand, especially the so-called public firm, with dispersed ownership and whose stock can be publicly traded. The political nature of the corporation is implied within the dynamic model of capitalism. Opposing views, disputes, and conflicts within the corporate system are already anticipated within corporate law as the board of directors is granted the authority to make decisions on the basis of the so-called business judgment rule, which prevents, e.g., courts from second-guessing the board's true intentions ex post facto (Boatright, 1994: 404). As directors have fiduciary duties vis-à-vis the corporation (Brudney, 1997; DeMott, 1988), which operates sui juris as an autonomous legal entity, shareholders and other stakeholders cannot overreach their contractual rights stipulated by share ownership. Still, this legal mechanism, empirically substantiated by numerous court cases, does 
not per se prevent corporations from being political entities as such. Instead, corporations are market-based entities that in various ways seek to create benefits for themselves, or, in the second instance, to create market conditions or influence regulatory frameworks that indirectly benefit their interests. Such tactics and strategic actions are not in any way unlawful, albeit certain actions may become so if certain mandatory rules or legislative frameworks are violated. Market-based actors and the wider public may still regard certain corporate activities as questionable on the basis of moral, ethical, and business practices grounds, despite such decisions being within the roughly defined landmarks of law.

Regardless of such beliefs and assessments, the distinction between unlawful and a more largely unflattering managerial behavior remains decisive in the current legal and regulatory framework. Nevertheless, the zone between what is unlawful, being the legal scholars business, and what is simply inadequate or incompetent behavior, wherein so-called "reputational loss" is incurred by corporations, is the management scholar's field of inquiry. Furthermore, this zone wherein managerial decisions are either tangential to unlawful behavior (say, tax evasion) or what is merely a disputed corporate practice (say, tax avoidance) is a political and politicized domain wherein various actors advocate, e.g., legal reforms or stricter (or, alternatively, more liberal) economic frameworks to better prevent certain undesirable practices (say, fraud-on-the-market cases; Fox, Fox, and Gilson, 2016). For instance, much of the corporate governance literature revolves around economists' and legal scholars' argument regarding how laws and regulations should be formulated to maximize economic welfare, and how to effectively allocate resources in the economy. Needless to say, events in this politicized zone of managerial decision making is the grist-for-the-mill for various scholars, business journalists, and pundits who pay close attention to, e.g., novel business practice (say, the offshoring of production, or various finance market operations) to assess their consequences for economic welfare and third parties.

\section{CASES OF POLITICIZED DECISION MAKING IN ORGANIZATIONS}

Erikson and Hamilton (2018) argue that the legal invention of the incorporated, chartered business triggered political debates regarding economic affairs and trade in the early modern period, from 1550 to 1720 . In the U.K., the "chartered company" was unusual and was also granted considerable privileges. Consequently, this new class of companies incited resentment among non-elite merchants, elite merchants located outside London, and free-trade protagonists in parliament more widely. Furthermore, in comparison to the leading economic nation at the time, the Dutch Republic of the Netherlands, 
the U.K. had weaker merchant representation in parliament for most of the seventeenth century (Erikson and Hamilton, 2018: 125). As a reaction to these political conditions and institutional changes, the very existence of chartered companies generated "written controversy, which found its way into the printing presses and public sphere," Erikson and Hamilton (2018: 141) write. In this view, the activities of chartered companies provided an "[i]nternal discursive space that fostered debate and argumentation" (Erikson and Hamilton, 2018: 112). The increases in the number of chartered companies were thus "significantly associated with increases in the publication of economic texts," which in turn were co-produced with a variety of social and economic changes in the U.K. in the period, e.g., "increases in gross domestic product, disruptive political and economic events, population growth, rates of overseas trade, state tax revenues" (Erikson and Hamilton, 2018: 113). The political decision to enact corporate laws (an issue covered in more detail in Chapter 2 of this volume) was thus not only associated with a modernization and liberalization of economic policy, but factually served as the primus motor of such changes, Erikson and Hamilton (2018: 113) argue: "[I]t was neither states nor markets that directly stimulated the development of this new institution, but instead organizations bridging the two, thereby creating a new type of public dialogue." In this view, the legal invention of the incorporated business served to leverage economic policy and contributed to the abandoning of the mercantilist doctrine that dominated to date. Furthermore, this historical record indicates that corporations, not then and still not today, exist and operate in isolation from the wider social community. Instead, companies do exist in the middle of intricate social relations.

When introducing the murky concept of politics (or even the curious linguistic construct "the political" as some kind of free-standing entity), the line of demarcation between the inside of the firm and its outside, an important issue in, e.g., corporate law and court ruling, is no longer fully applicable, nor meaningful. As the capitalist economic system is constituted as a capillary network of contracts, mutual agreements, and obligations across and between industries and corporations, and between corporations and the sovereign state and its defined agents, the binary model of inside/outside becomes increasingly inoperable. What happens inside the firm, say, in the domain of managerial decision making, is a matter of the current political situation, as such decisions transgress the boundaries between legal entities and institutional domains. Similarly, when corporations make decisions regarding, e.g., whether to lay off workers, or invest in more on-the-job training, such decisions have considerable ramifications throughout the social system, which includes political activities prompted by such decisions. Nevertheless, it is complicated to conduct an analysis of existing conditions unless there are meaningful variables and categories, so, for pedagogical reasons, it is useful to still distinguish between 
inside decision making in corporations, and political activities located outside the corporation's sphere of operation.

In the following sections, a number of cases of how corporations are affected by the political climate during a certain period of time, and in specific socio-economic and political settings, will be addressed. This literature represents a certain "outside-in" view of how politics affects corporations, legally instituted as free-standing entities that own themselves, and therefore, at least in theory but also in actual court case rulings, insulated from the political milieu wherein the corporation operates. Thereafter, a few studies of how corporations actively participate in or support various "inside-out" political activities are examined, that is, corporations that are involved in shaping the political and economic milieu wherein they operate, on the local, regional, and global scale. Seen in this view, corporations or their agents (say, industry interest organizations, employer organizations, chambers of commerce, and similar entities) actively seek to influence the political climate to their own or their beneficiaries' advantage.

\section{The Outside-in View}

In an entangled economic-political system, there are no closed spheres being protected from the circulation of political ideas, or sheltered from the consequences of undesirable political decisions or policy making (Battaglini and Patacchini, 2019). Instead, political ideas and political decision making are conducted locally and at the apex of the political system, and thereafter diffuse throughout the economy, at times with certain unintended consequences or biases, noise, and forms of informational losses following or occurring underway. Gupta and Wowak's (2017) study of Chief Executive Officer (CEO) compensation in public companies is indicative of this "open system" view of the economic-political system. Reporting data from the U.S., the study examines how political preferences and convictions of the board of directors, who negotiate the economic compensation package with presumptive CEOs, shape the final compensation package. The empirical evidence indicates that conservative boards (i.e., boards wherein the majority of the directors are Republican Party voters) and liberal boards (boards including a majority of Democratic Party voters) are paying an equal amount for low levels of performance, whereas conservative boards are more prone to pay generously for high levels of performance (Gupta and Wowak, 2017: 19). The data shows that one standard deviation in the board conservatism measure, ceteris paribus, is associated with approximately 4 percent higher compensation. This 4 percent growth in what the CEO takes home may seem marginal, but given the level of CEO compensation in the U.S. economy, with the median annual CEO economic compensation being $\$ 3.6$ million, this translates into an additional 
$\$ 144,000$ per year in compensation (Gupta and Wowak, 2017: 19). This $\$ 144,000$ per year is equivalent to more than three times the U.S. national average wage in 2014. When serving a conservative board of directors, a CEO can thus add another three years of national average compensation to his/her stipulated median compensation of \$3.6 million.

This preference for higher compensation for positive performance among conservative directors is justified by the proposition that monetary compensation (above other forms of compensation, including, e.g., informal rewards and reputational benefits) is inherently desirable and therefore "instrumental in retaining CEO talent" (Gupta and Wowak, 2017: 22). ${ }^{1}$ In contrast, liberal boards may either treat corporate performance as the outcome of the efficient management of a team production effort, which would easily result in an overcompensation of the CEO (which incurs costs for, e.g., shareholders), or may make the decision to not overcompensate CEOs on the basis of the proposition that CEOs are not exclusively motivated by monetary compensation anyway, but respond to a broader set of stimuli to perform at the peak of their performance. In the latter case, the concept of "money illusion" (Akerlof and Shiller, 2009: 41) has been introduced to denote the fallacious belief that monetary rewards and economic compensation are the only functional incentives when shaping human aspirations and behavior. The money illusion is indicative of an operative image of human preferences and decision making as being exclusively oriented towards so-called extrinsic motivation. In either situation, CEOs are compensated most generously and at a historically unprecedented level, regardless of the political preferences of the directors. Under all conditions, Gupta and Wowak's (2017) study shows that the party lines of American politics are mirrored in the CEOs' economic compensation packages, which means that the line of demarcation between corporations and the wider political system is permeable.

Another domain wherein political conviction among executives and directors plays a key role in shaping the political climate is the view of unionism and the role of trade unions in the corporate system. As detailed by Akard (1992), the period 1974 to 1981 was characterized by a transformation in U.S. policy, wherein prominent business leaders and "lobbying groups representing all segments of capital" mobilized to disarm unions. Among conservative business leaders and their allies, the growth in federal legislation in the 1965-1975 period, which targeted a wide number of issues including workplace safety, environmental pollution, and product quality, in combination with more clearly articulated compensation demands from trade unions, was an unbearable combination, deemed to pose a threat to the autonomy of American industry. Business leaders viewed this state-led advancement of regulatory control as a tendency towards collectivism or even a form of socialism, which they regarded as being intolerable for various reasons, not least because it 
undermined the American self-image of "the land of the free," once and for all leaving the shackles of authoritarian European political systems, which included monarchies, aristocracies, and religious authorities, behind. After the inauguration of Ronald Reagan as president in January 1981, the ultimate triumph of this business community's mobilization, the pro-business policy of the Reagan administration included a not so covert anti-unionism credo, effectively first rolled out during the Air Controllers' strike, organized by their union PATCO, in 1981 (Jacobs and Myers, 2014: 755).

The fierce anti-unionism of the conservative business community treated trade unions as a source of unsustainably inflating labor costs, well beyond the productivity growth, but the historical record does not support such claims. Instead, real wage growth moved roughly in tandem with productivity growth until around 1970, and thereafter labor's share of the reported profits has gradually declined, which indicates a divergence between productivity growth and real wage growth (Gordon, 2015: 542). That is, rather than advocating unreasonable expectations regarding compensation, unionism served to keep economic inequality in check. As, e.g., Ahlquist (2017: 426) shows, trade unions are associated with "more compressed distributions of wages and incomes, both before and after government taxes and spending." Even though trade unions are explicitly political organizations, their role in the post-Second World War period was not for most part to extract unreasonable levels of compensation, but to ensure that stable economic growth was maintained over the economic cycle and in a long-term perspective. Seen in this view, the overtly skeptical view of trade unions among conservative business leaders was motivated by political convictions rather than economic evidence. Under all conditions, the business community and the corporate system once again acted in ways that simultaneously affected the corporate system and the wider society, which indicates the "two-way traffic" between managerial decision making and the broader political and social system.

In summary, corporate executives and the board of directors make decisions based on conventional wisdom and the political climate for the time being, but they are also in the position to make decisions that influence the external community. In this view, there is a certain political economy of the corporation, as corporate decision making does not take place in a social vacuum. Instead, corporate decision making and policies are made in a context wherein they have economic, political, and social implications, both inside and outside the firm. In addition, the "inside-out view" of corporate decision making underlines how political engagement and campaigns to modify business rules and regulatory control, or to promote legal reforms are part of an economic-political agenda pursued by corporate decision makers. 


\section{The Inside-out View}

In the inside-out view of political activities, corporations are not merely passively responding to external changes in the market, in the regulatory milieu, or society more generally, but actively work to enhance their capacity to compete in the market. When being active in the marketplace, there are several mechanisms that secure benefits for the corporation, which include insurances from the sovereign state, subsidies, regulatory reforms, and various exemptions regarding, e.g., taxation. For instance, the construction industry is the primary provider of the housing that serves as collateral in the capital formation process. As the sovereign state is assumed to insure major finance institutions that issue credit in the form of home mortgage loans against default, a housing-finance nexus is established (Schwartz, 2012). In the finance industry, the sovereign state issues licenses that grant the right to trade, e.g., certain commodities, which provide many opportunities and advantages vis-à-vis competitors that do not have the benefit of participating in both the trade of commodities and the financial operations derived from the trade (Omarova, 2013). In cases wherein a specific industry, e.g., the finance industry, is dissatisfied with the regulatory framework, innovations may force regulators to take action, which results in either stricter regulatory control, or legal reforms consistent with corporate interests (Funk and Hirschman, 2017). Corporations do therefore have considerable opportunities to negotiate their role and function in the wider economic system, by negotiating rights and responsibilities.

Abraham and Ballinger (2012: 445) examine how the pharmaceutical industry actively seeks to influence the regulation of clinical trials, wherein a new candidate drug is, e.g., tested in a human population and a reference group. Formally speaking, it is a strictly regulated process, monitored by authorities such as the Food and Drug Administration (FDA) in the U.S. and comparable agencies elsewhere. Abraham and Ballinger (2012: 445) argue that in the regime of the "neoliberal regulatory state," being considerably more responsive to the commercial interests of the pharmaceutical industry, new clinical trial practices and new "test systems" are successfully advocated by the pharmaceutical industry. More specifically, Abraham and Ballinger (2012: 465) examine a specific carcinogenicity test that evaluates the risk that a presumptive patient will get cancer from consuming a particular drug. In the model advocated by the pharmaceutical industry, empirical evidence of the lack of carcinogenicity in a candidate drug derived from in vivo studies of so-called gene knock-out mice, a genetically modified animal, is "satisfying evidence." This model is advanced despite the fact that the biological system of genetically modified mice differs from the human biological system, and clinical evidence that shows that cancer is often associated with other biological or exogenous conditions, not reducible to the "genetic make-up" as 
such, Abraham and Ballinger (2012: 465) say. To use Nelson's (2013) term epistemic scaffold, which denotes how a specific experimental system (say, an in vivo model, including knock-out mice) to a varying degree mimics actual biological conditions "in the wild," Abraham and Ballinger (2012) argue that the new carcinogenicity test, which exclusively relies on a single genetic test model, fails to account for all the risks involved when the new drug is tested. That is, the proposed experimental system fails to convince skeptical commentators regarding the positive and robust relationship between the clinical data generated within the experimental system and the actual consequences for presumptive patients who are prescribed the medication being tested.

Abraham and Ballinger (2012: 468) regard the fragility of the proposed model as indicative of the pharmaceutical industry's ambition to cut down on costs to prove the efficacy and safety of a candidate drug. In a regulatory milieu wherein agencies are under pressure from industry, and indirectly also from the political system, responsive to, e.g., lobbyist campaigns and direct campaign donations, short-cuts and far from perfect clinical trial models are more likely to gain a foothold in an otherwise strictly regulated new drug development process. In this new regime, profit motives are actively invoked when negotiating what was previously regarded as strictly scientific concerns, including, e.g., the design of clinical trials. Abraham and Reed (2002) show that the pharmaceutical industry actively advocates new standards for clinical trials.

Hadani and Schuler (2013) and Lux, Crook, and Woehr (2011) examine how corporations invest in Corporate Political Activity (CPA) to receive certain benefits that affect long-term performance and the survival of the corporations. Hadani and Schuler (2013: 166) operationalize CPA as "Corporate Political Investments" (CPI), in turn defined as investment in "lobbying, campaign contributions, and hiring former public officials." Whereas Lux, Crook, and Woehr (2011) find a positive correlation between CPA and corporate financial performance, and suggest that firm size is the strongest predictor for CPI, Hadani and Schuler's (2013: 166) results reveal no such benefits:

Our results strongly suggest that CPI is not profitable, and indeed may be detrimental to firm performance. We find that firms' political investments are significantly and negatively related to market valuation and firms' cumulative political investments are likewise significantly and negatively related to market valuation and return on sales (ROS). (Hadani and Schuler, 2013: 166)

Hadani and Schuler (2013: 176) suggest that this result is explained on the basis of inadequate assumptions regarding the benefits of CPA, and that senior managers, consistent with agency theory, may have "personal reasons," including "self-aggrandizement, ideological beliefs, desire to voice" to invest 
in CPA. Based on such assumptions, executives may divert internal resources into "political pursuits" rather than investing these resources in "more lucrative market activities" (Hadani and Schuler, 2013: 176). That is, CPA is a form of political strategy that substitutes rather than complements the market strategy. However, arguably consistent with Lux, Crook, and Woehr's (2011) result, making firm size the foremost predictor of CPA, Hadani and Schuler (2013: 177) found that firms in regulated industries that invested in CPA “enjoyed superior market returns to firms with lower investments." Such results indicate that corporations being politically active in markets subject to regulatory control may influence the regulatory practices through investment in political activities.

Another domain wherein managerial decision making and policies enacted by boards of directors influence the political system is campaign contributions to political parties or individual politicians. This blending of business and political interest is particularly salient in the U.S. political context, but there is evidence of similar practices and tendencies in what political pundits refer to as "stable democracies" across the world. For instance, in Sweden, widely treated as a transparent democracy with few scandals related to the manipulation of the election system historically, the conservative party, Moderaterna, has occasionally refused to reveal its campaign contributions. In the U.S., campaign contributions, primarily from wealthy individuals, is "big business," as the American democracy is based on a form of clientelist model wherein individual congressmen/congresswomen and senators are responsible for raising their own funds to finance their political campaigns. As many commentators have remarked, this model sits uneasily with stated democratic political ideals, as it is primarily a small proportion of the population that contributes the lion's share of the campaign funds, in the next instance putting the political system at risk to overstate certain interests over other, potentially more pressing or socio-economic relevant concerns.

Bonica et al. (2013: 111) report that the share of the total income received by the top 0.01 percent of households is about 5 percent in the U.S. Yet the contribution to the aggregated campaign funds from this group of "high net-worth households" exceeds 40 percent. Studies show that high net-worth households have historically financed the two major parties in relatively equal terms (the presidency of Bill Clinton, 1993-2001, for instance, largely relied on Wall Street donations, which eventually translated into liberal finance market laws and regulations, for some moderate commentators being the key explanation for the 2008 finance industry meltdown), but the pendulum has now swung in favor of the Republican Party during the recent elections (Bonica et al., 2013: 113). For instance, in the 2012 election cycle, the 0.01 percent community outspent the labor community by a factor of four-to-one, a figure that arguably 
indicates systemic economic inequalities in American society (Bonica et al., 2013: 113)

Regarding corporate campaign donations, there is a literature that indicates that U.S. corporations actively support political campaigns that benefit their interest. In the 2012 election cycle, for instance, the finance industry (including donations from individuals) gave over $\$ 670$ million in campaign contributions (Levitin, 2014: 2044). In addition to these "general donations," it is possible to trace money flows associated with specific legislative processes that affect the finance industry. Mian, Sufi and Trebbi (2010: 1969) examine the legislative process that materialized when the Emergency Economic Stabilization Act (EESA), a piece of legislation being part of the resolution system implemented after the sub-prime home mortgage market collapse, was passed in Congress. When the money flows between donators and politicians were examined, Mian, Sufi and Trebbi (2010: 1969) found that a strong predictor of the voting behavior was the amount of campaign contributions from the financial services industry. Mian, Sufi and Trebbi (2010: 1969) suggest that this result is consistent with "anecdotal evidence" that suggests that the finance industry invested heavily in lobbying to shape EESA to converge with its own interests. Of particular interest is the fact that the donations targeted politicians running for reelection, and thus "highly sensitive to past campaign contributions," and politicians that represented constituencies with a high degree of sub-prime mortgage borrowers among their voters. Furthermore, and "unsurprisingly," Mian, Sufi and Trebbi (2010: 1969) write, "we find that conservative ideology strongly predicts votes against the two bills." In conclusion, Mian, Sufi and Trebbi (2010: 1997) state that their findings unambiguously establish a robust relationship between campaign donations and voting behavior (and, by implication, the outcome from the policy making process): "Our results are consistent with the hypothesis that politicians voted in favor of the EESA in part due to special interest campaign contributions from the financial services industry."

On the basis of such evidence, the campaign donation system is disputed and treated as a violation of stated democratic ideals, resounding in American institutions, and which Americans of all political hues tend to hold in esteem. For the defenders of the current system, the American democratic model makes politicians responsive vis-à-vis their voters and thus cannot ignore the practical problems and challenges their constituencies have to deal with. Unfortunately, this latter argument carries the most validity only in the case where there is reasonable equality in terms of what interests the entire stock of finance capital donated represents. What has been called "vending machine politics" is largely incompatible with democratic ideals, wherein the parliament represents the interests of the people, not the highest bidder on a political auction. Despite 
such claims, currently, the campaign donation model seems to be relatively well tolerated across the party borders.

\section{TO SUGAR-COAT THE PILL: COVERING UP POLITICAL OBJECTIVES THROUGH THE USE OF METRIC, QUANTA, AND OTHER HEURISTICS}

If policy making and the design of regulatory control systems are riddled by disputes or conflict, there is a need to move beyond the existing arguments and information to reach farther. As, e.g. the economist Paul Romer (2015: 89) remarks, "Politics does not lead to a broadly shared consensus. It has to yield a decision, whether or not a consensus prevails. As a result, political institutions create incentives for participants to exaggerate disagreements between factions." In this view, politics is a system that pronounces and leverages disagreements, which provide, e.g., voters with discernable alternatives, but also have the adverse effect of creating a sense of dissent even in the case wherein political representatives have shared interests. This predicament in combination with everyday political rhetoric and polemics being based on the use of terms and phrases that are evocative and ambiguous makes political discourses a fragile shared ground for deliberation. Kroll et al. (2017: 700) remark that the political system is unequipped to make decisions that can be implemented straightforwardly, which leaves policy making as a political process wherein the substance of the policy is to be determined elsewhere, and after the decision is already made, in the regulatory agencies and among other agents responsible for the implementation of political decisions:

Ambiguity stemming from political stalemate essentially passes the buck for determining details from legislators to someone later on in the process. These later actors tend to be more sheltered from political pressures and thus able to make specific decisions without risking their jobs at the next election. Judges and administrative agencies frequently fill this role. Courts are expected to offer impartial decisions resistant to public pressure, and administrative agencies are expected to retain staff who offer subject-matter expertise beyond what is expected of legislators, despite changes in political administrations. (Kroll et al., 2017: 700)

In this view, the political system only provides the roughly defined grids for the regulatory activities, of necessity making day-to-day industry regulation a form of afterthought, pushed onto the regulatory agencies outside of the media limelight (Riles, 2011), where policy can be translated into the technocratic pursuit to monitor business activities.

In order to translate policy statements into factual regulatory control, a variety of heuristics have been developed and implemented, including the use of devices such as indicators (Merry, 2016), measures (Desrosière, 1998), 
league tables and other commensuration means (Espeland and Stevens, 1998), algorithms (Johns, 2016), forms of audits (Power, 2003), and self-assessment and auto-surveillance techniques (Richards, 2013). The primary purpose of such heuristics is to downplay or even mask underlying political objectives and to make, e.g., regulatory control appear as a strictly technical affair. "[M]easures immediately entail a whole politics of visibility: rather than simply being epistemic constructs, measures are a domain of practical action," Brighenti (2018: 29) writes. She (2018: 25) elaborates:

[M]easures are not simply tools in our hands, they are also environments in which we live. While our focal awareness is inevitably attracted towards measures as technical devices and formal procedures, from the moment in which measures become infrastructural they also become an "air" that we breathe, an atmospheric component of society. (Brighenti, 2018: 25)

This translation of a political decision - a new policy, say-into a widely agreed and tolerated regulatory activity or practice is apparently far from trivial and demands some detailed analysis.

The scholarly literature points both at debates and controversies concerning new regulatory control, and at more complicated concerns (after all, politics is the practice of reconciling opposing interests and beliefs), that is, how the heuristics being introduced to support political objectives migrate to serve other ends than those originally intended and being their raison d'être (Rona-Tas, 2017). For instance, Brayne (2017: 980) studied the use of a "big data and algorithms" information system called Palantir, used by the Los Angeles Police Department (LAPD). The principal driver for the use of such a decision-assisting system, intended to support the police officers in their day-to-day field work, is how such systems confer legitimacy to everyday practices, ultimately based on the purported "scientific nature" of the system. In cases wherein human discretion is being questioned - as it is within LAPD on a recurrent basis - the combination of big data and algorithmic predictions emerges as a palatable solution to police work legitimacy challenges. Formally speaking, Palantir, which has also been purchased by federal agencies such as the Central Intelligence Agency (CIA) and Federal Bureau of Investigation (FBI), other police departments such as New York Police Department (NYPD), and banks such as JP Morgan, is introduced as a system that "polices the police." Aggregated data on police practices is advertised as what may shed light on "systematic patterns and institutional practices previously dismissed as individual-level bias, ultimately providing an opportunity to increase transparency and accountability," Brayne (2017: 997) writes.

Brayne's (2017: 997) empirical evidence speaks against such claims that this represents an idealized view of Palantir, which instead operates in the 
opposite direction wherein the hidden assumptions of the system become self-reinforcing. While the advocates of the system suggest it is "just math," a declaration intended to confer scientific authority to the system to render it value-neutral under the aegis of "scientificity," and therefore reliable and trustworthy, Brayne (2017: 997) suggests that existing inequalities mirrored in how the LAPD monitors the citizens are further amplified: "[M]athematized police practices serve to place individuals already under suspicion under new and deeper forms of surveillance" (Brayne, 2017: 997). Palantir is based on the calculation of what is called a point value: the estimated risk of a typical subject acting suspiciously or unlawfully on the basis of historical data, including "objective data" that covers parameters such as race, residential address, previous crimes, etc. The concern is that the point value, constructed on the basis of the ambition to avoid "legally contestable bias in police practices" (Brayne, 2017: 997), results in uses of algorithmic data that serve to create a self-perpetuating cycle wherein individuals or specific communities with higher point value are under heightened surveillance, and therefore are exposed to a greater risk of being interrogated by the police, which further increases the point value of these individuals or communities. Furthermore, the Palatir system does little to solve the underlying conditions conducive to a higher degree of criminal behavior in certain communities; that is, through the self-reinforcing mechanisms of the algorithm, already socially vulnerable groups are unable to escape from the loop wherein their point value increases as stricter police surveillance is justified on the basis of the purportedly value neutral, ‘just math' model. Brayne (2017: 1004) summarizes her findings:

Far from eliminating human discretion and bias, big data represents a new form of capital that is both a social product and a social resource ... Characterizing predictive models as "just math," and fetishizing computation as an objective process, obscures the social side of algorithmic decision-making. (Brayne, 2017: 1004)

As Christin (2018: 1411) argues, concepts such as rationalization, accountability, and transparency, all part of a mainstream regulatory framework and vocabulary, are often stated objectives of decision makers who introduce metrics to achieve stipulated goals. Quite frequently, Christin (2018: 1411) adds, "what happens on the ground often differs from these grand intentions." "Big data and algorithms" decision making systems are undoubtedly the most recent thrust in governance theory and practice, celebrated as devices that transcend the carefully catalogued "behavioral biases" of human decision makers (see, e.g., Kamenica, 2012). But the benefit of having human decision makers (say, politicians, CEOs, directors, etc.) is now concealed under a veneer of fabricated scientific respectability. For lay audiences, an algorithm is a highly abstract entity, and when decision makers, previously held accountable for 
their actions, suddenly confer authority to abstract algorithms, they also sideline themselves, as their expertise, judgment, and authority is no longer vital for the operations because big data and algorithms now do the job for them. The celebration of big data and algorithm devices in decision making communities is thus a puzzling phenomenon, as such communities actively undermine their own positions, stating that their domain of expertise can at low cost and with limited unintended consequences be substituted by algorithm-based decision making systems.

Regardless of the fallacy of believing that decision making communities can maintain their authority when they downplay their accountability through the transfer of decision making capacities to abstract systems and devices, the larger question is how such groups came to believe in the efficacy of big data and algorithm systems, or other governance systems being introduced that confer authority from individuals to metrics and quanta. To better shed light on that question, an "inside view" of the corporate control system will be examined and, more specifically, studies of the use of accounting will be reviewed.

\section{Corporate Decision Making and Governance: Accounting as Politics Pursued by Other Means}

Miller and Power (2013) argue that the tendency to use advanced metrics is salient in contemporary governance practice, more focused on avoiding blame than getting credit for outcomes, as suggested by Krippner (2007: 478): "[A]ccounting increasingly provides the dominant narrative of market rationality within organizations, among organizations, and at a societal level," Miller and Power (2013: 558) write. For Miller and Power (2013: 559), the acclaim of formal metrics is again based on what John Dewey ([1929] 1988) referred to as "the quest for certainty," an ambition to create quanta that appear "objective and unchallengeable," and are safely located beyond "the fray of politics or mere opinion." In everyday practice, accounting serves two roles: to fulfil the legal demands for how corporate entities report their earnings and costs to audiences, and to communicate the performance of the corporation with finance market actors to lower information costs among traders, now better accessing univocal and formal firm-specific data. Furthermore, inside the corporation, Miller and Power (2013: 562) suggest, accounting metrics increasingly play an "adjudicating role," which denotes that accounting is intended to evaluate the performance of individuals (e.g., CEOs) and organizations (units or entire corporations). In accomplishing this complex social role, accounting is based on the premise of conferring responsibilities to individuals, now being held accountable and responsible for the calculated performance, in equally good times and bad times. 
The proposition that accounting is the process of instituting formal metrics as an indicator of both performance and accountability means that individuals subject to accounting practices cannot be entirely cynical regarding the nature of accounting, nor its role within the corporate system. There are of course debates and skepticism regarding the calculation, or uses, of certain metrics, but individuals involved in accounting work, or directly subject to discriminate performance measures based on accounting figures need to believe in their accuracy and legitimacy. Brighenti (2018: 29) argues that measures enable social actors to align objectives and goals with "logical" and "quantitative" terms, but the alignment of objectives and terms is dependent on the joint capacity to turn what social actors want into what they believe. To function effectively, accounting needs to be based on the credo that measures and quanta (individual measures further calculated into, e.g., ratios or bundled into commensuration devices such as league tables) do in fact stand in for something, and that a corporate activity is worth pursuing on the basis of the resources committed to the activity. "[A]ccounting is not just a matter of technical calculation and information provision for decision-making, but also a vehicle for the realization of economic ideas and the economization of the enterprise," Miller and Power (2013: 592) say. In summary, seeing is believing, but more importantly believing implies a certain way of seeing - a seeing shaped by the accounting figures being jointly established and agreed upon.

Mazmanian and Beckman's (2018) study of the accounting process in an American hotel chain, very much "number-driven," is illustrative of how abstract figures gradually come to constitute a joint credo among managers. Speaking about the annual budget review process, located in the SeptemberOctober period, as a "ritual," Mazmanian and Beckman (2018: 357) underline how the process to establish "normative control" is entangled with the creation of "robust output control." In this ritualized process, accounting figures were far from clear at the beginning of the process, but over the cycles of negotiations and modifications of "the numbers," the participants came to see the outcome as "reified and reasonable" (Mazmanian and Beckman, 2018: 363). The use of George Simmel's term reification (Verdinglichung) is indicative of how the lifeworld of the managers, who were responsible for the economic performance of either one entire hotel or a unit within a hotel, tended to regard the numbers of the budget process as politically justified performance measures that should be met under all conditions. The primacy of budget goals was the principal corporate governance mechanism in the hotel chain: "A hotel not performing to budgeted expectations was a poorly performing hotel, regardless of other metrics" (Mazmanian and Beckman, 2018: 364). This quest for predictable outcomes on the basis of purportedly transparent performance goals had the adverse effect of putting managers under great pressure to deliver what was stipulated by the numbers. One of the interviewees, the sales associate 
Natalie, just about to exit the corporation on the basis of strict managerial discipline, witnessed to an "atmosphere of fear and panic in the end-of-quarter stress," imposed on managers "trying to make their numbers" (Mazmanian and Beckman, 2018: 365). It is questionable whether the hotel managers and their middle managers would have tolerated this periodicity of "fear and panic" unless they were invited to participate in the budget process, wherein they themselves actively translated rather vague market signals into accounting figures, gradually stabilized in the budgeting ritual process. Through the budgeting ritual, performance measures on the unit level was established as a means of ensuring normative control of the managers, who were now willing to submit to what they regarded as numbers representing objective truths and output control, i.e., the aggregated performance of the entire hotel chain, of interest to, e.g., finance market actors who monitor the financial performance of public firms. Ultimately, the budget process served to transfer responsibilities from top management to hotel managers and their middle managers, who now agreed to perform as stipulated by the numbers.

This overtly political process of imposing responsibilities on managers with limited capacity to determine, e.g., market conditions or macroeconomic events that strongly affect their business (after all, hotel services have relatively low price elasticity, i.e., hotel bills are one of the first costs that corporations, public sector organizations, and households may cut down on in the face of more uncertain economic prospects) was veiled by the uses of numbers and the budget ritual as such: "Numbers are often used in organizations as seemingly objective tools by which interests are advanced yet justified with a professional, precise, and depersonalized language ... Political and social processes are masked by numbers," Mazmanian and Beckman (2018: 377) summarize. A failure to deliver satisfying results was consequently understood as the manager's own failure, and not as evidence of unreasonable expectations or ill-constructed measures, being either biased or failing to account for systemic risks or other market conditions reasonably beyond the influence of any ambitious hotel managers (or combinations thereof).

In summary, corporate interests are advanced in a political domain and climate wherein a variety of stakeholders actively participate to ensure that their concerns are included in, say, a policy making process. Corporations and industry interest organizations access considerable economic and financial resources and have much "skin in the game," and consequently they can choose from a variety of strategies when seeking to influence policy making (e.g., direct negotiations, lobbying, campaign donations, think tank funding). Under certain conditions, such overt activities may be ineffective in assisting stipulated goals, and in such cases the use of metrics and quanta, associated with scientific authority and separated from the stubborn skepticism of common sense thinking, serves to mute ideological discourses and 
narratives and to render them as being little more than a thinly veiled and self-serving rhetoric. To escape this dead end of political discourses, of necessity self-referential and therefore continuously generating more responses and comments, gradually making the factual issue at hand a secondary concern, metrics and quanta ensure traction in political processes. As interests and ideologies are increasingly enshrined within the metrics and quanta per se, now gradually being accepted by larger shares of the community, the process can move on, eventually being translated into proper action in targeted domains. In the end, the use of accounting and accompanying metrics and quanta is based on the willingness to forget original controversies to benefit a meaningful implementation of the new practices. At the same time, as indicated by the studies of Brayne (2017) in the civil service sector and Mazmanian and Beckman (2018) in the corporate system, the uses of metrics and quanta easily throw the baby out with the bathwater as the critical reflection on the use of the metrics and their social and economic consequences are abandoned, at times even prohibited.

Furthermore, the successful implementation of such systems is frequently followed by a form of social amnesia (Dobbin and Sutton, 1998: 472), a forgetfulness regarding the epistemic and political difficulties involved when establishing metrics and quanta in the first place, and how these tools were originally considered as experimental activities subject to critical assessment and accompanying reflection, which essentially precludes self-reflexive uses of such tools once they have been established. Instead, the day-to-day use of metrics and quanta gradually disappears into the infrastructure of management practice and governance activities. In this view, the uses of metrics and quanta are far from unproblematic as the issue of reification looms, the concern that a certain measure, say, a credit rating score, may be indicative of more personal qualities than what it strictly purported to measure in the first place, the parametric calculated risk of not repaying a loan being issued by a creditor (in the case of the so-called FICO score; see Rona-Tas, 2017).

In addition, when authority is conferred to metrics and quanta and the managerial or governance systems that generate and use these figures, decision makers downplay the accountability that justifies their role in the politicaleconomic system in the first place, now making intricate political decisions essentially a matter of a faceless technocracy devoid of human interference (Merry, 2016). Such technocratic tendencies are conducive to what Pasquale (2015) refers to as a black-box society, wherein a growing proportion of decisions are made by algorithms that are legally speaking private property and thus protected from scrutiny by corporate law (Kroll et al., 2017). Needless to say, the dream of a political system devoid of disputes and opposing views cannot be entirely displaced by a "big data and algorithm" regime, as the ques- 
tion of accountability is always already implied whenever political decision making discretion is granted or assumed.

\section{OUTLINE OF THE VOLUME}

The remainder of this volume is structured into five chapters. In Chapter 2 , corporate law is examined as a legal device introduced to encourage and promote enterprise and risk-taking, preferably also resulting in economic welfare effects including job growth and income subject to taxation. The legal device of corporate legislation is thus historically determined as the sovereign state actively confers rights and liabilities to the incorporated business. In this view, the incorporated business is a privately owned economic entity that owns itself, yet is recognized as a legal subject within the realm of the state. The legal invention of the incorporated business includes a variety of rights such as the authority to handle its reported income as stipulated by specific rules that apply to this class of businesses, and this bundling of rights and liabilities, enshrined by corporate law, renders several shareholder-friendly arguments irrelevant. While the question of shareholder activism is further examined in Chapter 5, the second chapter provides an overview of how corporate legislation as a constitutive law bestows the board of directors with the authority to manage the corporation with discretion.

Chapter 3 discusses how economic policy and regulations are constitutive of not only markets and market practices, but also shape and inform incorporated businesses such as public companies and closely-held firms (i.e., firms with a limited number of owners of stock, e.g., family-owned businesses). In this view, regulatory practices are not simply understood as additional checks and balances, imposed by centrally located policy makers and their defined agencies, each being somewhat skeptical regarding the capacity of markets to self-stabilize and businesses to self-regulate in, e.g., the case of a major downturn in the economic cycle. Instead, regulatory practices are treated as important elements of the market making activities, being part of the policy makers' political assignment.

The fourth chapter introduces the concept of "market for political influence" to shed light on how the current market creation and regulation processes are informed and structured by various forms of political activities. These activities are either financed or sponsored by corporations directly, as in the case of lobbyism, or indirectly through think tank funding or political campaign donations by industry interest organizations and chambers of commerce, or by private individuals who support pro-business policy making by donations to political parties or individual politicians they believe honor this credo. The concept of the market for political influence is somewhat polemic, as it indicates that markets are not so much naturally occurring sites for economic 
transactions as they are human fabrications, i.e., institutions, which per se are social and political accomplishments, and that continue to be subject to political influence long after their inception.

Chapter 5 reviews the literature on corporate social responsibility (CSR) as being a more recent theme in the management studies literature and in business practice more widely. Rather than treating CSR as a genuine commitment to economic welfare, some commentators regard CSR campaigns as a concession in an era where businesses are essentially self-regulating and escape most wider social responsibilities (including, e.g., to provide stable and predictable work opportunities, and to ensure real wage growth for employees), as they instead emphasize the enrichment of shareholders as a key priority. In this view, the question regarding the social responsibilities is a corporate governance question, a long-standing concern in the management studies literature. The latter half of the chapter covers the literature that assesses the shareholder benefit of CSR investment, and discusses the economic and social value of CSR in a situation wherein the traditional role of the corporation as a primacy risk-bearer in the economy is largely surrendered. These issues are of relevance for a scholarship that regards the incorporated business as a key entity in the joint creation of economic welfare, which ultimately justifies competitive capitalism vis-à-vis competing economic models (e.g., state-governed capitalism in the Chinese style).

The sixth and final chapter summarizes the key points made and demonstrated in the previous chapters, and invites a more open-ended discussion regarding the future of the incorporated business and competitive capitalism as a viable economic system. Drawing on the seminal work of the Austrian school of economics scholar Joseph Schumpeter, the political view of the corporation may be an essentially more complicated analytical model than the "minimal theory" of the firm as a bundle of contracts/financial assets promoted by, e.g., free-market theorists. On the other hand, this minimal model may be analytically elegant and can make generous use of Ockham's razor to cut off purportedly unnecessary fat from the model. Yet, to ignore that the incorporated business is a politically embedded entity from the bottom up, in its legal protection in corporate law and in and through the regulatory practices that determine its operations, is to miss much of the point with the corporate form, its ability to create economic welfare that benefits not just a small proportion of the market participants or the population. This group now includes an elite of finance traders and capital owners, claiming their share of the residual cash generated in a specific economy annually on precarious grounds, in equally theoretical and empirical terms. The choice between a more complex and convoluted analytical model, and a more-easy-to-apply but analytically thin model should be easy in the best of possible worlds. Sadly, that is not of necessity the world that this scholarship is pursued within. 


\section{SUMMARY AND CONCLUSION}

Management studies include a large variety of theoretical perspectives, methodological approaches to the object of study, and empirical research programs. It is only infrequently that the term politics is used to characterize how, e.g., corporations are formed and operated in a milieu structured on the basis of political objectives. This volume explores how political interests and political processes serve to structure the laws, regulations, and day-to-day practices that constitute the corporations as economic entities. Corporate law serves to create and recognize the corporate entity as a legal entity bestowed with certain rights and liabilities. Regulations set up rules and standards for how the corporate entity should act in the marketplace to generate a profit and to create economic value. The market for political influence is the arena wherein various actors compete over the ability to influence laws and regulations, in many cases being a process wherein corporations act through their defined agents, e.g., lobbyist firms or industry interest organizations. Finally, in addition to the laws and regulations, to a varying degree imposing mandatory rules, there are social norms regarding the responsibilities of the corporate entity. Such norms are either endorsed by the corporation itself, as a concession in exchange for other benefits and the freedom to operate within the jurisdiction, or norms and expectations formulated by other actors-consumer groups, activist groups, etc.- - who seek to impose new practices on corporations. In either case, CSR denotes a wider set of concerns that fall outside what laws and regulations stipulate. Taken together, the corporate entity is brought into this world as a legal device subject to certain political ideas, and in its operations it remains within a domain characterized by competing and heterogeneous interests. Politics may be an overused word, but it still apprehends the embedded nature of the corporation.

\section{NOTE}

1. Jacobs and Dirlam (2016) substantiate the claim that the Republican Party voters believe in economic compensation as a mechanism conducive to enterprise and risk-taking more widely (including the individual's willingness to invest in tertiary education). Speaking about economic inequality, per se a "negative" construct for most commentators (some conservative commentators take a more sanguine view of economic inequality, and treat it more as a motivator for disfavored groups than as evidence of some "unfairness" in the economic system), an effect of how e.g., economic compensation is distributed in a working population but also being dependent on fiscal policies and other political decisions that shape the transfer system, Jacobs and Dirlam (2016: 483) show that the three Republican presidential administrations (Ronald Reagan, George H. W. Bush, and George W. Bush) resulted in an 11.6 percent growth in economic inequality on average. Regardless of economic policies of Republican presidents, economic inequality seems to be 
treated as a lesser matter within the American political system at large, as indicated by the decline of the real value of the minimum wage, which declined by 45 percent (after being adjusted for inflation) from its peak in 1968 to 2006 (Bartels, 2008: 226). That is, not even Democratic presidents have been successful, potentially not even interested, in making economic inequality a political objective beyond legal and regulatory reforms that are purportedly beneficial for economic growth and enterprise, and per se treated as a mechanism that evens out economic inequality over time. 